\title{
Characterization of Soil Bacterial Diversity in Relation to Irrigation Water: A Case Study in China
}

\author{
Guangwei Huang1, W. Saki Takahashi², Huan Liu'1, Tamao Saito², Nobutada Kimura ${ }^{3}$ \\ ${ }^{1}$ Graduate School of Global Environmental Studies, Sophia University, Tokyo, Japan \\ ${ }^{2}$ Faculty of Science and Technology, Sophia University, Tokyo, Japan \\ ${ }^{3}$ Bioproduction Research Institute, National Institute of Advanced Industrial Science and Technology, Tsukuba, Japan \\ Email: huang@genv.sophia.ac.jp
}

How to cite this paper: Huang, G.W., Takahashi, W.S., Liu, H., Saito, T. and Kimura, N. (2016) Characterization of Soil Bacterial Diversity in Relation to Irrigation Water: A Case Study in China. Journal of Water Resource and Protection, 8, 10901102.

http://dx.doi.org/10.4236/jwarp.2016.812086

Received: September 25, 2016

Accepted: October 30, 2016

Published: November 2, 2016

Copyright $\odot 2016$ by authors and Scientific Research Publishing Inc. This work is licensed under the Creative Commons Attribution International License (CC BY 4.0).

http://creativecommons.org/licenses/by/4.0/

\begin{abstract}
Use of wastewater for irrigation has become indispensable worldwide due to accelerating water scarcity, and it also carries a social dimension of poverty reduction in developing countries. However, the impacts of wastewater irrigation on soil properties are still insufficiently understood, especially with regard to change in soil microbial community characteristics. The present study presents an assessment of soil bacterial communities subjecting to different irrigation waters. We conducted soil sampling in farmlands irrigated with wastewater, river water and groundwater respectively in an arid region of China and performed a metagenomic survey of microbial populations using the prokaryotic $16 \mathrm{~S}$ ribosomal RAN gene. It sheds new light on possible alteration of soil bacterial diversity due to irrigation water. It also reveals that the relative abundance of nitrifying bacteria is greater in soil irrigated with river water than soil irrigated with wastewater. The opposite is true for denitrifying bacteria. The findings serve as a call for further in-depth study to explore the long-term responses of soil microbial communities to irrigation waters for the sake of environmentally sound watershed management.
\end{abstract}

\section{Keywords}

Irrigation, Microbe, Richness, Diversity, 16S rRNA Gene, Heihe River

\section{Introduction}

The use of wastewater in agriculture is known to have been practiced for centuries in developing countries of Asia [1] and is also a common practice in the water scarce regions of the developed world such as Australia, south west USA, Florida, and densely populated European countries such as France, England and Germany [2]. A historical 
turning point of waster reuse occurred in the 1880s when Louis Pasteur and Robert Koch discovered pathogenic microbes and modes of disease transmission. Since then, the industrialized countries of the world have taken on an almost obsessive fear of disease transmission by pathogen-laden wastewater and established strict and costly health guidelines and standards for wastewater reuse. Although opinions have varied widely as to the benefits and health risks associated with wastewater irrigation over the past 150 years, the use of wastewater in agriculture is regaining momentum as an emerging priority, encouraged by governments and official entities worldwide in consideration of the increasing demand for fresh water and increasing production of wastewater resulting from population growth, urbanization, living standard improvement and industrial development. Since $40 \%$ of the world's population will face water stress or scarcity within the next 50 years, the use of wastewater represents a justifiable pathway toward sustainable development.

It is estimated that more than 4 - 6 million ha of farmland are irrigated with wastewater or polluted water [3] [4] [5]. A separate estimate indicates that the figure reached to 20 million ha globally, an area that is nearly equivalent to 7 per cent of the total irrigated land in the world [1].

In rural regions of developing countries, wastewater treatment is often not possible due to limited financial resources, and small, old or non-extendable sewerage systems. Therefore, the use of wastewater in agriculture can also help to minimize pollution of the ecosystem caused by direct disposal of wastewater into surface or groundwater. Raschid-Sally and Jayakody [6] suggest from a survey across the developing world that wastewater without any significant treatment is used for irrigation purposes in four out of five cities. Hussain et al. [7] report that raw or partially treated wastewater is used for irrigation in 50 developing countries. Ujang and Henze [8] point out that 95 per cent of wastewater generated enters the environment without proper treatment.

Based on these findings, it may be inferred that wastewater irrigation in developing countries has largely been carried out with raw or insufficiently treated wastewater. Considering the potential risks to the environmental and public health, the main problem with the growing trend toward more wastewater irrigation is that the practice either involves the direct use of untreated or insufficiently treated wastewater, or the indirect use of polluted waters from rivers and streams that are the recipients of untreated or insufficiently treated wastewater discharges in low income countries, but also many middle-income countries as well. Thus, for sustainable reuse of wastewater, impact assessment of wastewater reuse without treatment or with insufficient treatment must be conducted thoroughly from various angles.

Irrigation with wastewater may impact soil at two different levels, altering the physicochemical and microbiological properties of the soil. The first may affect soil productivity and fertility while the second may pose serious risks to human and environmental health.

On the other hand, wastewater can be considered as a valuable source for plant nutrients and organic matter needed for maintaining fertility and productivity of arid 
soils. It is estimated that $1000 \mathrm{~m}^{3}$ of municipal wastewater applied to one hectare can contribute 16 - $62 \mathrm{~kg}$ of organic nitrogen, $4-24 \mathrm{~kg}$ of phosphorus, $269 \mathrm{~kg}$ of potassium, 18 - $208 \mathrm{~kg}$ of calcium and $9-110 \mathrm{~kg}$ of magnesium each year [9]. A number of studies have shown that the use of wastewater improved both the physicochemical properties of the soil and crop yield. For instance, Singh et al. [10] conducted a year-long experiment on effects of sewage wastewater irrigation and revealed that the use of domestic wastewater with fertilizers brought about improvement in the physicochemical properties of the soil, crop yield and also in the nutrient status as compared to that resulting from the application of groundwater with fertilizer. A study by Yang et al. [11] also showed that sewage irrigation could increase the production of vegetables and improve soil fertility. Hanjra et al. [12] reported that the use of wastewater for irrigation may be a source of beneficial bacteria for soils. Similar results were also reported by other studies [13] [14].

Nevertheless, field experiments conducted by Mohammad Mazahreh [15] showed that wastewater irrigation decreased soil $\mathrm{pH}$ and increased soil salinity, soil phosphorus, and increased soil organic matter only in the topsoil. Ndour et al. [16] evaluated the effects of groundwater versus urban wastewater irrigation regimes on a sandy agricultural soil through chemical and microbial analyses. Their study indicated that soil chemistry and total bacterial community were not affected by the two different irrigation regimes.

Despite that the responses of soil properties to wastewater irrigation deserve in-depth investigations from different aspects, the effects of wastewater irrigation on soil microbiota are indeed much neglected in the majority of studies on irrigation with wastewater according to the study of Becerra-Castro et al. [17]. Therefore, given the importance of soil microbial communities in relation to sustainable agriculture, studies should be promoted to fill up this major knowledge gap.

The present study is designed to examine the structure of soil microbial communities in relation to irrigation water through a field study in an arid region in Northwest China for better understanding the drivers of environmental change. We investigated soil bacterial at multiple sites subjected to different irrigation practices and here we present our findings for the purpose of information dissemination, enriching the literature and serving as a call for further comprehensive in-depth studies.

\section{Materials and Methods}

\subsection{Site Description}

The Zhangye basin, or the middle reaches of the Heihe River, was chosen as the study area. The Heihe River is the second largest inland river in China. With a length of 821 $\mathrm{km}$, its main stream, originates from the Qilian mountains of Qinghai province, flows through the Zhangye basin, and ends up in the Inner Mongolia Autonomous Region. The catchment of the middle reaches, or the Zhangye basin, covers an area of $1.08 \times 10^{4}$ $\mathrm{km}^{2}$ extending from $38^{\circ} 30^{\prime} \mathrm{N}$ to $39^{\circ} 50^{\prime} \mathrm{N}$ and $99^{\circ} 10^{\prime} \mathrm{E}$ to $100^{\circ} 52^{\prime} \mathrm{E}$. Along the main stream, the middle reaches start from the Yingluo Gorge and end at the Zhengyi Gorge 
(Figure 1).

The Zhangye basin is characterized by a dry continental climate, with mean annual precipitation of less than $200 \mathrm{~mm}$, and annual potential evaporation of $2000 \mathrm{~mm}$ or more. The renewable water resource per capita in Zhangye is $1250 \mathrm{~m}^{3} / \mathrm{yr}$, just $5 \%$ of the world average. Under such a natural condition, agriculture in this region is only possible via irrigation. Due mainly to farmland expansion which led to higher irrigation water demand and also due partly to population increase, the water consumption in the Zhangye basin started increasing since the 1960s. The annual surface water consumption in the 1980s was twice as high as in the 1970s and the increasing trend continued into the 1990s. This overuse of water in the middle reaches caused severe ecological degradation in the downstream resulting in the drying up of East Juyan Lake in 1992 and the drying up of West Juyan Lake even earlier. To restore the ecosystem of the downstream Heihe River basin, a water allocation policy was launched by the Chinese central government in 2000, which mandates $0.95 \times 10^{9} \mathrm{~m}^{3}$ of water per annum be diverted to the downstream when the annual runoff at the entrance of the middle reaches is not less than $1.58 \times 10^{9} \mathrm{~m}^{3}$ [18]. Because $50 \%-60 \%$ of the total river discharge has been diverted annually from the middle to the lower reaches of the river following the water allocation regulation, groundwater abstraction increased causing groundwater level decline in certain areas of the middle reaches. For the period from 1980 to 1992, the rate

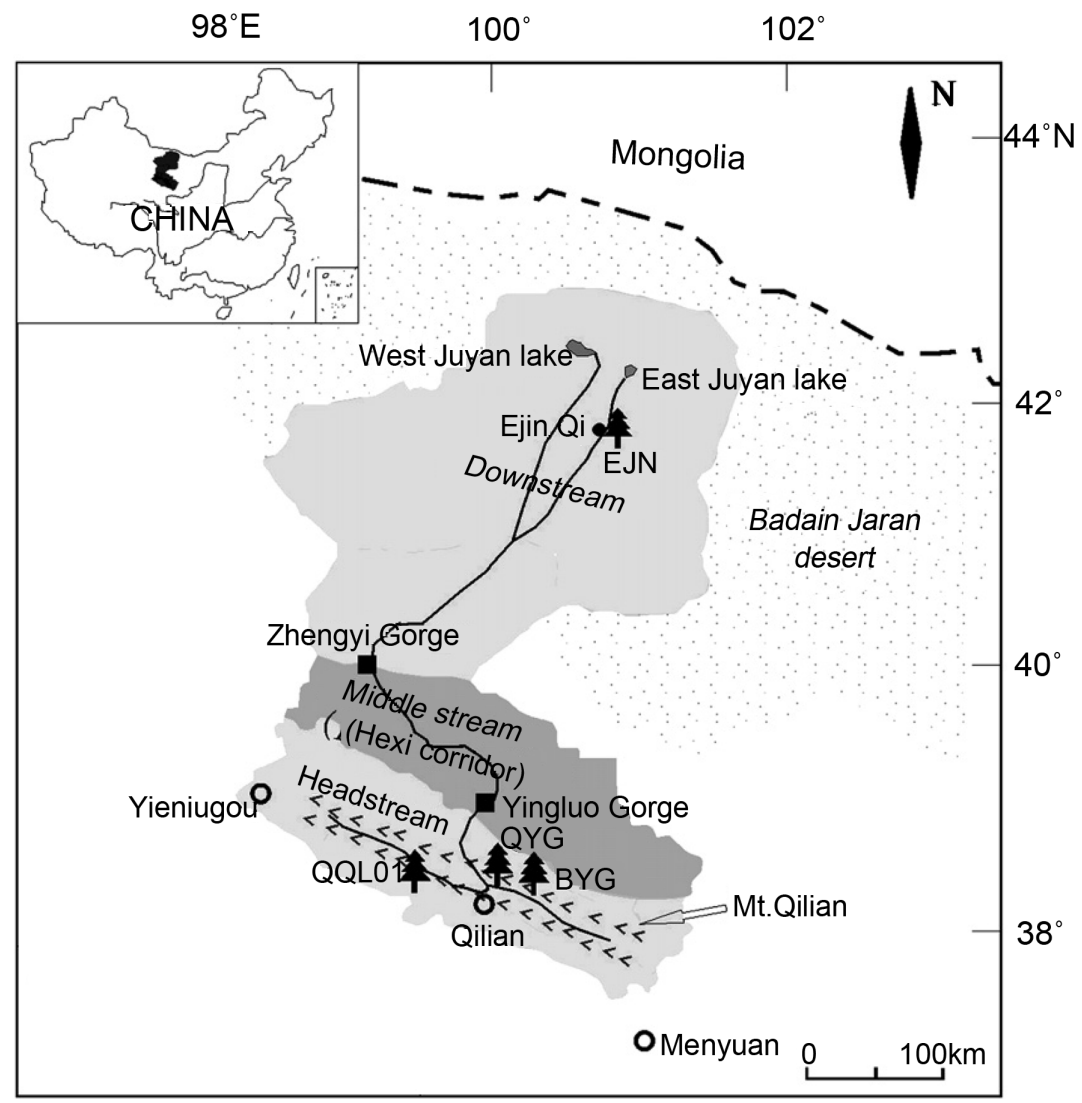

Figure 1. Watershed of the Heihe River. 
of ground water depletion varied from $0.09 \mathrm{~m} / \mathrm{yr}$ to $0.31 \mathrm{~m} / \mathrm{yr}$ among 7 monitoring stations in the basin while the rate depletion increased to the range of $0.31 \mathrm{~m} / \mathrm{yr}-0.89$ $\mathrm{m} / \mathrm{yr}$ for the period of 1999-2004 [19]. Another recent analysis on groundwater-levels of 42 observation wells in the middle reaches of the Heihe River revealed that the groundwater levels generally decreased between 2000 and 2010, which led to the reduction of shrub forests and an increase in grassland desertification in particular areas [20]. To meet the needs of protecting the downstream environment and conserving the groundwater resources in the middle reaches without affecting the livelihood of farmers in the Zhangye basin, the Zhangye government established policies toward watersaving society, promoting the planting of crops with less water demand and subsidizing the use of advanced irrigation techniques such as sprinkle and dripping irrigation and prohibited rice production because of its high water demand. In addition to crop structure adjustment and use of advanced irrigation techniques, another technical solution to compensate for the reduced river water supply in the Zhangye basin is wastewater reuse, which can provide not just another source of irrigation water but a source of plant nutrients, allowing farmers to reduce fertilizer use. According to our field survey, wastewater reuse for irrigation has been put into practice for more than a decade in certain areas of the Zhangye basin, which motivated the present work.

\subsection{Methods}

A field survey was conducted in the Zhangye basin in July 2015. Four types of farmland were selected: three fields cultivating maize but using different types of irrigation water and another field cultivating chili pepper using mainly groundwater but sometime river water. We included such a site having different crop in this field study in order to explore the possibility of improving soil microbial diversity through planting different crops. At the time of the field survey, $\mathrm{COD}, \mathrm{NH}_{4}^{+}-\mathrm{N}$ and $\mathrm{NO}_{3}$ concentrations of wastewater flowing into farmland were measured to be $>8 \mathrm{mg} / \mathrm{L}, 10 \mathrm{mg} / \mathrm{L}$ and $60 \mathrm{mg} / \mathrm{L}$, respectively. Therefore, it may be categorized as insufficiently treated wastewater. The use of wastewater for irrigation in this area has been practiced since 2002.

From each of the river water irrigated, wastewater irrigated and two groundwater irrigated fields, 8 soil samples were taken from the surface layer of $10 \mathrm{~cm}$. At each site, soil $\mathrm{pH}$ and soil temperature of the surface layer were measured. Soil illumination was also measured in light of the discovery of bacteriophytochromes in non-photoautotrophs. The site information is compiled in Table 1. Besides, the nitrate contents of sampled soils were also measured with Horiba LAQUA twin for Soil following the manufacturer's manual.

To identify bacterial community structure, total soil DNA was extracted with soil DNA isolation kit (Norgen, ON, Canada) according to the manufacturer's instructions with minor modification. We used skimmed milk as a competitor described as previously [21]. The purity of soil DNA was examined with agarose gel electrophoresis and quantified by measuring $260 \mathrm{~nm}$ absorbance. 16S ribosomal DNA V3-V4 region was amplified with following primers: 
Table 1. Sampling site information.

\begin{tabular}{cccccc}
\hline Irrigation water type & latitude & Longitude & Soil Tem. $\left({ }^{\circ} \mathrm{C}\right)$ & Soil pH & Illuminance \\
\hline River water $(\mathrm{Rw})$ & $38^{\circ} 53^{\prime} 14.4^{\prime \prime}$ & $100^{\circ} 20^{\prime} 05^{\prime \prime}$ & 25 & 7.0 & low \\
Wastewater $(\mathrm{Ww})$ & $39^{\circ} 00^{\prime} 16.7^{\prime \prime}$ & $100^{\circ} 30^{\prime} 44.4^{\prime \prime}$ & 23 & 7.0 & low \\
Groundwater $(\mathrm{Gw})$ & $39^{\circ} 00^{\prime} 15.6^{\prime \prime}$ & $100^{\circ} 30^{\prime} 41^{\prime \prime}$ & 25 & 7.0 & Low + \\
Mixed water $(\mathrm{Gw}-\mathrm{w})$ & $38^{\circ} 51^{\prime} 19.6^{\prime \prime}$ & $100^{\circ} 22^{\prime} 05.18 .9^{\prime \prime}$ & 23 & 6.5 & low- \\
\hline
\end{tabular}

16S (V3-V4) Amplicon PCR Forward primer: 5'

TCGTCGGCAGCGTCAGATGTGTATAAGAGACAGCCTACGGGNGGCWGCAG- 3'

16S (V3-V4) Amplicon PCR Reverse primer: 5'GTCTCGTGGGCTCGGAGATGTGTATAAGAGACAGGACTACHVGGGTATCTAA TCC-3'.

The PCR program used was as follows: initial denaturation at $95^{\circ} \mathrm{C}$ for $3 \mathrm{~min}$, then 25 cycles consisting of denaturation at $95^{\circ} \mathrm{C}$ for $30 \mathrm{sec}$, annealing at $55^{\circ} \mathrm{C}$ for $30 \mathrm{sec}$ and extension at $72^{\circ} \mathrm{C}$ for $30 \mathrm{sec}$, followed by final extension at $72^{\circ} \mathrm{C}$ for $5 \mathrm{~min}$ and hold at $4^{\circ} \mathrm{C}$. The PCR products of $16 \mathrm{~S}$ V3-V4 region were purified with AM Pure XP beads (Beckman Coulter Inc. CA USA) according to the manufacturer's instructions. The amplicon libraries with different barcodes were pooled and sequenced on Ilumina MiSeq sequencing instrument with 300bp pair end sequencing by Hokkaido System Science Co Ltd. The sequencing data were analyzed with standard Quantitative Insights Into Microbial Ecology (QIIME) pipeline and low quality reads and adaptor contaminations were eliminated by Hokkaido System Science Co Ltd.

To evaluate alpha diversity of soil bacterial, richness or the number of OTUs (Operational Taxonomic Unit), and Chao 1 index were employed. For beta diversity measures, Bray-Curtis index and Weighted UniFrac distance were calculated with QIIME.

\section{Results and Discussions}

A total 60,212 OTUs were identified from all 32 soil samples and the average number of OTUs was 1881 per sample. Figure 2 shows the OTUs (clustered at a 97\% similarity) abundance levels of the four sites. Species richness is significantly higher in the river water irrigated field compared to the wastewater irrigated field. Since the river water irrigated field is a few kilometers away from the wastewater irrigation field, and the difference in species richness between the two sites when the practice of wastewater irrigation begun was not known, the current difference may be considered as due not totally but largely to irrigation water. For the groundwater irrigated field, which is next to the wastewater irrigation site, the OTUs abundance level is as low as the wastewater irrigated field. This suggests that wastewater irrigation may have affected the quality of surrounding groundwater. For the groundwater irrigated field cultivating chili, which is distant from the wastewater irrigation site, the species richness is also significantly higher than the wastewater irrigated field, which can be considered as the result of combined effects of soil-plant interaction, soil spatial variability and irrigation water. 
This provides a hint that degraded soil bacterial diversity could be restored via crop selection. We hypothesize that Capsaicinoids contained in chili pepper might be an agent for promoting soil bacterial richness. Figure 3 shows the comparison of Chao 1 diversity index between the four sites. Like the OUTs abundance level, the alpha diversity index is significantly higher for the river water irrigated field than for the wastewater field ( $\mathrm{p}<0.001)$. On the other hand, the difference in Chao 1 index between the wastewater field and the groundwater irrigated field next to it was very small.

Hui et al. reported that an excess of nitrogen addition to soil significantly reduced alpha diversity [22]. Because the use of wastewater for irrigation adds more nitrogen

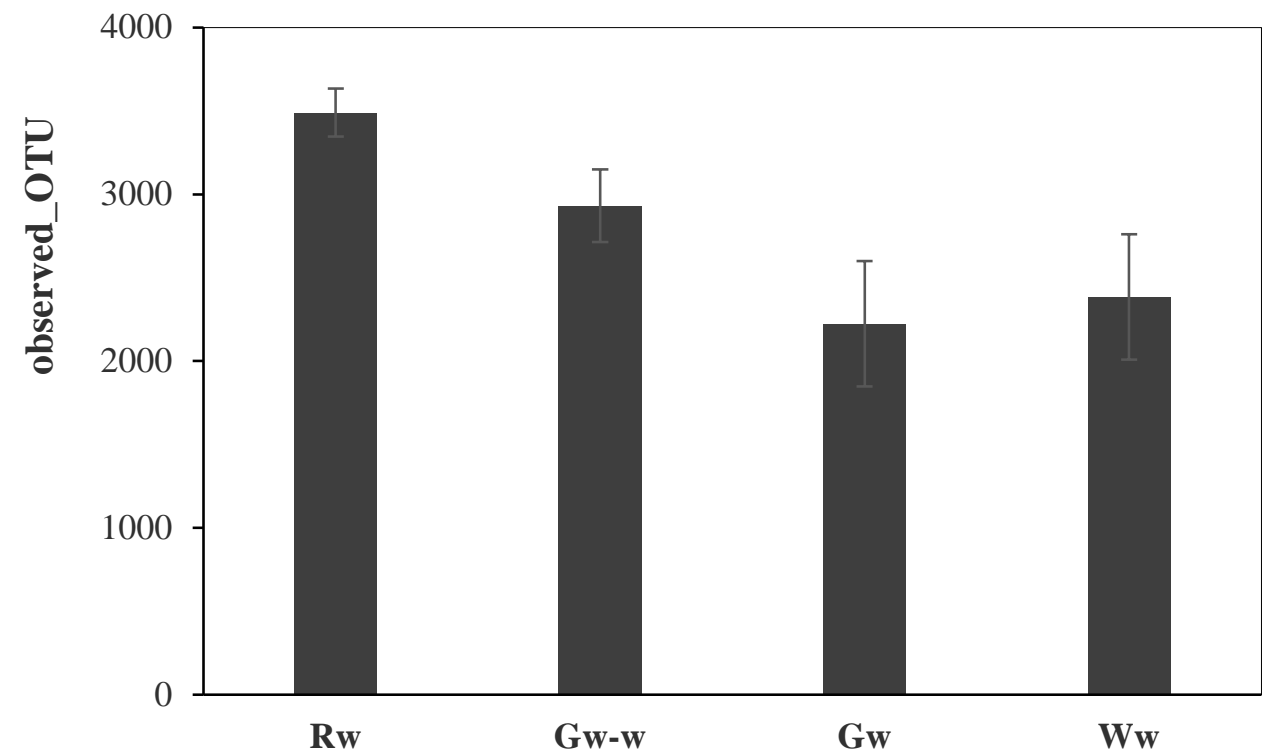

Figure 2. OTUs abundance levels of different fields.

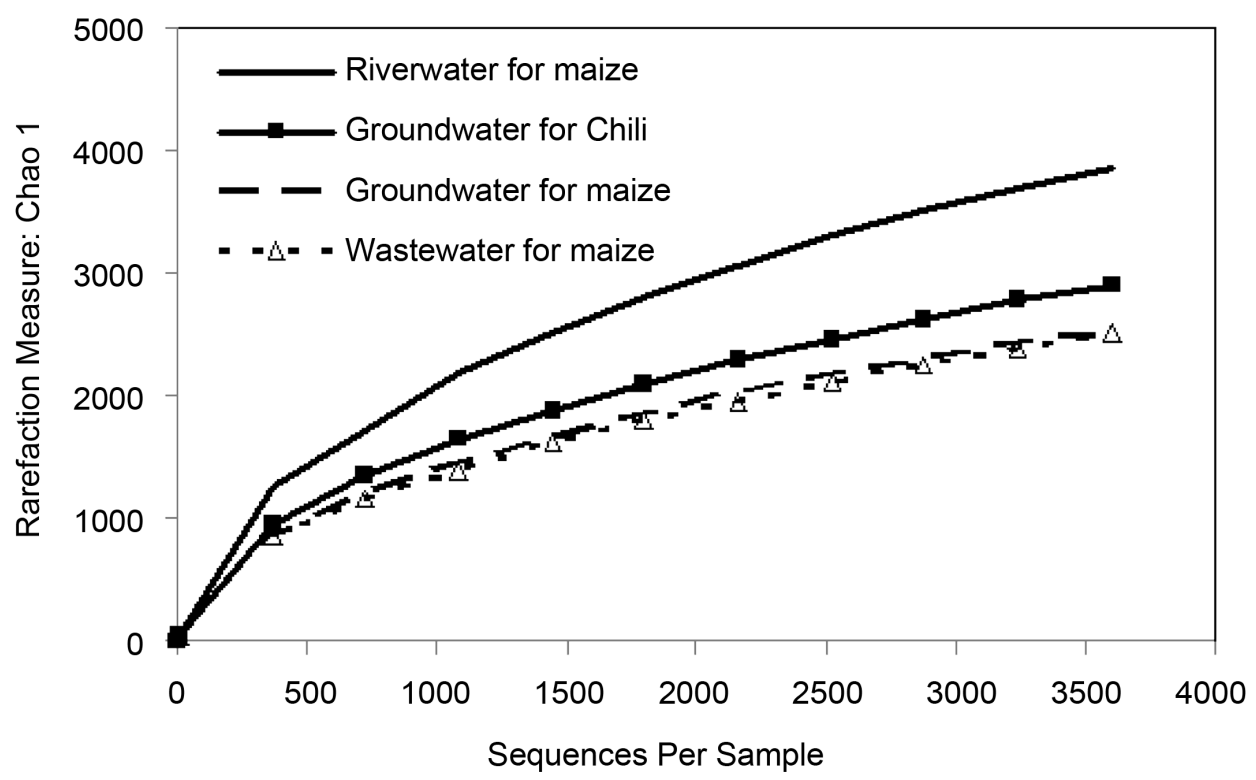

Figure 3. Diversity index for different fields. 
into soil than using river water, the relatively low alpha diversity of the wastewater irrigated field may be attributed to excessive nitrogen addition.

Figure 4 shows the results of Principal Coordinates Analysis (PCoA) generated with UniFrac showing clustering of OTUs bacterial groups of soil samples. Each type of samples formed a distinctive cluster in both weighted UniFrac distance and Bray-Curtis index. The dissimilarity between river water and wastewater irrigated soil samples can be attributed to human influence via effluent. On the other hand, studies in the 1950s and 1980s [23] [24] [25] have clearly demonstrated a distinct indigenous microbial community in subsurface waters as compared to surface waters. Therefore, the separation in cluster between soils irrigated by surface waters (both river water and wastewater) and irrigated by groundwater can be considered as a natural extension of the difference between surface and subsurface waters. Thus, the first coordinate may be viewed as indicating human impact such as excessive nitrogen addition while the second could be interpreted as an indicator of shift from surface to groundwater.

Nitrification has always been documented as a two-step process catalyzed by chemolithoautotrophic microorganisms oxidizing either ammonia or nitrite. However, a recent paper in Nature [26] reported the discovery of a completely nitrifying bacterium from the genus Nitrospira. The genome of this organism encodes the pathways both for ammonia and nitrite oxidation. Following this new finding, we scrutinized the microbial community composition of all sampling sites. Although microbial community composition varied between sites surveyed, Nitrospira were consistently detected.

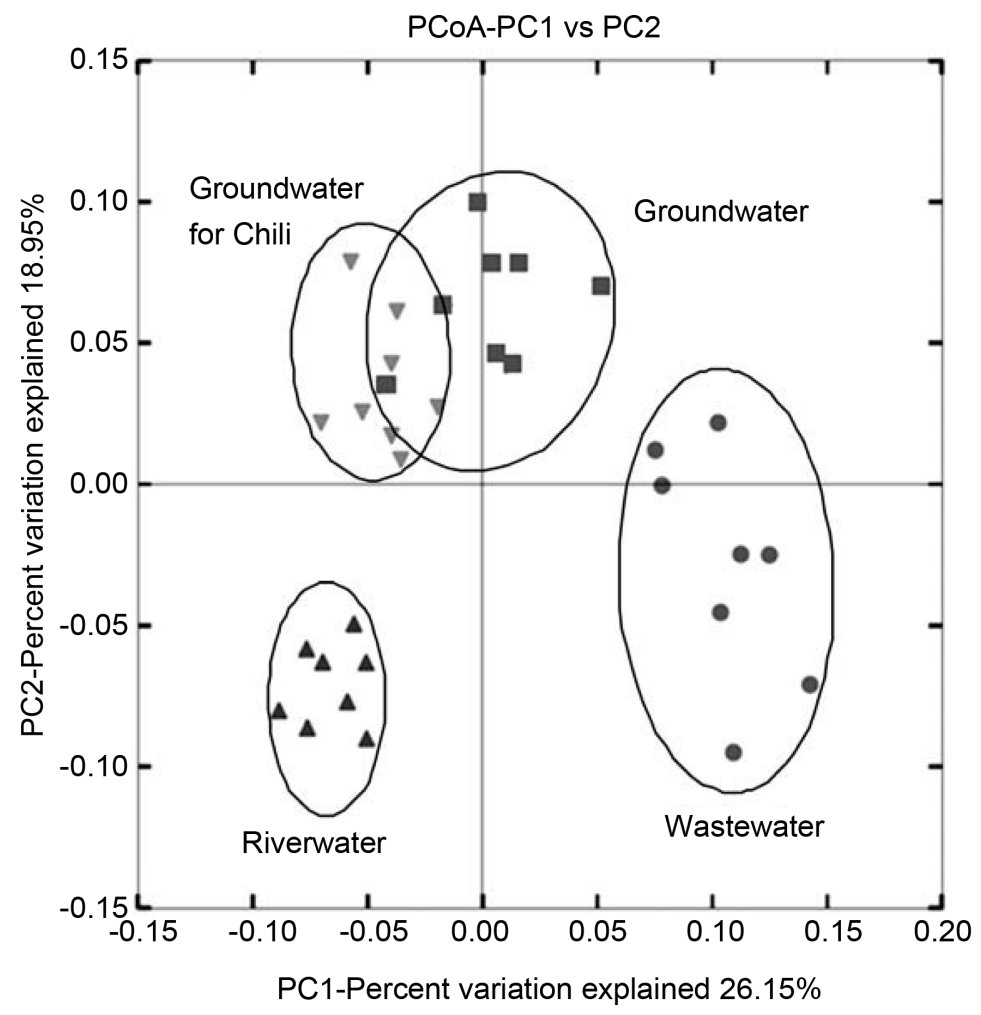

Figure 4. Results of principal coordinates analysis. 
The relative abundance is $0.99 \%$ at the river water-fed site, $0.66 \%$ at the groundwaterfed maize site, $0.79 \%$ at the groundwater-fed chili site and $0.41 \%$ at the wastewater-fed site. The completely nitrifying process may eliminate the intermediate product of nitrite, which is toxic.

The three main sources of nitrogen used in agriculture are urea, ammonium and nitrate. Urea and ammonium fertilizer application involves the conversion of ammonium to nitrate. Whether or not a complete nitrifying process is better than the two-step nitrification process in terms of the resistance to losses of nutrient from the soil by leaching is a question worth exploring. If the complete nitrifying process were advantageous, the present study would be viewed as evidence of another demerit of wastewater irrigation and measures should be sought to increase completely nitrifying bacterium in wastewaters.

On the other hand, denitrifying bacteria was also examined. Paracoccus denitrificans was not detected but Pseudomonas was found present in all sites. The relative abundance is $0.43 \%$ at the site using wastewater, $0.1 \%$ at the sites using river water and groundwater for maize cultivation and $0.037 \%$ at the site using groundwater for chili cultivation. This finding could be supported by the study of Friedel et al. [13], which demonstrated that soil denitrifying activity was stimulated with long-term wastewater irrigation as compared to those under rain-fed agriculture. Such a finding may lead one to hypothesize that although wastewater provides a valuable source of nutrients, enhanced soil denitrification might cancel this benefit because denitrification results in the loss of nitrogen. On the other hand, the measurement of soil nitrate revealed that the mean concentrations of soil nitrate are $110 \mathrm{ppm}, 483 \mathrm{ppm}$ and $425 \mathrm{ppm}$ for river water-irrigated, groundwater-irrigated and wastewater-irrigated fields, respectively. This implies that wastewater irrigation led to significantly higher accumulation of nitrate in soil than river water irrigation. Such various derivations from the comparison of soil bacterial communities serve as a call for further study to provide new insight into the relationship between microbial communities and nutrient dynamics in soil.

Figure 5 shows 10 phyla detected in the four fields with relative abundance above $1 \%$. Among the 10 phyla, the largest difference in relative abundance between fields lies in Gemmatimonadetes.

In soil $16 \mathrm{~S}$ rRNA gene libraries, Gemmatimonadetes is one of the nine most commonly detected phyla, yet their ecology remains little known [27]. Overall findings from this study suggest that bacteria from the phylum Gemmatimonadetes are adapted to different types of irrigation water. Our results might also imply that Gemmatimonadetes in soil depends more on moisture availability since wastewater is more frequently available than river water for irrigation in arid region. Nevertheless, the ecological role of Gemmatimonadetes remains an open question.

In 2006, WHO published a third edition of its Guidelines for the safe use of wastewater, excreta and grey water in agriculture and aquaculture. In four volumes, these Guidelines propose a flexible approach of risk assessment and risk management in which quantitative microbial risk assessment (QMRA) is focused on excrete-related pathogens for assessment of human health. In the United States, each state government 


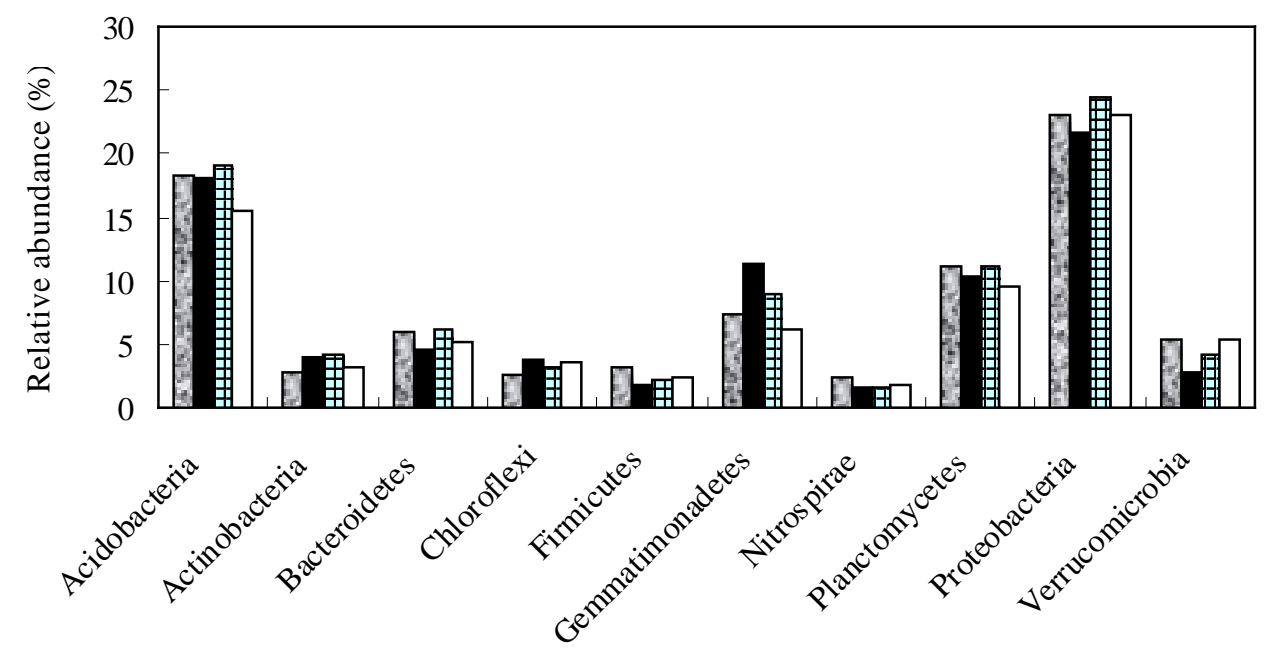

river water

wastewater $\mathbb{\boxplus}$ groundwater

groundwater for Chilli

Figure 5. Dominant phyla in surveyed fields.

sets their own microbe standard of irrigation water following the EPA's guidelines. They all target Fecal coliform or E. coli. Standardized procedure for detecting E. coli has been developed and widely used. For non-fecal bacteria, there is no good indicator so far. A study by Armon [28] found that zucchini irrigated with poor-quality wastewater accumulated higher levels of Cryptosporidium oocysts on the surface than other types of crop. Besides, a top priority must be given to minimizing heath risk to farm workers. Therefore, in addition to irrigation water standards, we propose a post-audit framework for evaluating long-term effects of wastewater reuse in agriculture as shown in Figure 6. It will target not just the alteration of physical and chemical properties but also microbial communities of soil; and in the same time it places emphasis on health effects on both farmers and consumers. The objective of the post-auditing is to improve wastewater irrigation standards and practices through evaluation of long-term effects based on monitoring data. We believe that the development of such a post-audit system will contribute to the better reuse of wastewater, which is essential to integrated watershed management.

\section{Conclusion}

In an arid region, the bacteria in soil irrigated with wastewater for a decade have a significantly lower richness and alpha diversity than soil irrigated with river water. The relatively low diversity may be attributed to excessive nitrogen input from wastewater. In-between lies the bacterial richness of soil irrigated with groundwater. However, for the groundwater-fed site close to the wastewater-fed site, its taxonomic abundance level is indifferent to that of wastewater-fed soil. It is also found that the relative abundance of nitrifying bacteria is greater in soil irrigated with river water than soil irrigated with wastewater and the opposite is true for denitrifying bacteria. Although it is a case study and the survey was limited in scope, the insights gained from this investigation contribute 


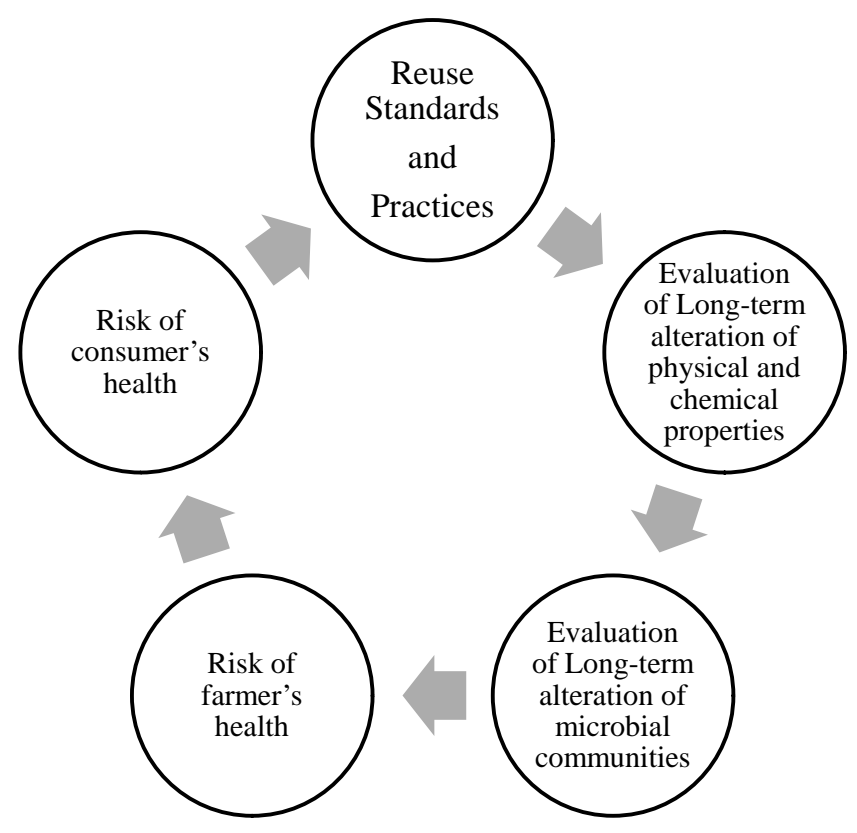

Figure 6. A post-audit system for wastewater reuse.

to better understanding of the coupling between soil bacterial and the characteristics of irrigation water. It enriches the literature by adding evidence of possible negative impact of wastewater irrigation on soil microbes and highlighting other potential issues. Besides, this paper proposes a post-audit framework for better management of wastewater reuse. Given that wastewater reuse for irrigation has become an indispensable alternative for water resource management in water-scarce regions across the world, the present study serves as a call for more in-depth studies assessing the safety of wastewater irrigation from a microbial perspective.

\section{Acknowledgements}

This work was supported by the Flagship Research Fund of Sophia University. We would like to thank Profs. Li Xin, Wang Jian, Che Tao, Wang Weizhen, Huang Chulin of the Chinese Academy of Sciences for their generous support for our field survey.

\section{References}

[1] WHO (2006) WHO Guidelines for the Safe Use of Wastewater, Excreta and Greywater. Vol. I: Policy and Regulatory Aspects. Vol. II: Wastewater Use in Agriculture. Vol. III: Watewater and Excreta Use in Aquaculture. Vol. IV: Excreta and Greywater Use in Agriculture. World Health Organization, Geneva.

[2] Marsalek, J., Schaefer, K., Excall, K., Brannen, L. and Aidun, B. (2002) Water Reuse and Recycling. Canadian Council of Ministers of the Environment, Winnipeg, Manitoba. CCME Linking Water Science to Policy Workshop Series. Report No. 3.

[3] Jimenez, B. and Asano, T. (2008) Water Reuse: An International Survey of Current Practices, Issues and Needs. IWA Publishing, London, $650 \mathrm{p}$.

[4] Keraita, B., Jiménez, B. and Drechsel, P. (2008) Extent and Implications of Agricultural Reuse of Untreated, Partly Treated and Diluted Wastewater in Developing Countries. $C A B$ 
Reviews. Perspectives in Agriculture, Veterinary Science, Nutrition and Natural Resources, 3, (58). http://dx.doi.org/10.1079/PAVSNNR20083058

[5] UNHSP (United Nations Human Settlements Programme) (2008) In: LeBlanc, R., Matthews, P. and Roland, P., Eds., Global Atlas of Excreta, Wastewater Sludge, and Biosolids Management: Moving Forward the Sustainable and Welcome Uses of a Global Resource, UN-Habitat, Nairobi, 632 p.

[6] Raschid-Sally, L. and Jayakody, P. (2008) Drivers and Characteristics of Wastewater Agriculture in Developing Countries: Results from a Global Assessment, Colombo, Sri Lanka. IWMI Research Report 127, International Water Management Institute, Colombo.

[7] Hussain, I., Raschid, L., Hanjra, M.A., Marikar, F. and Van der Hoek, W. (2001) A Framework for Analyzing Socioeconomic, Health and Environmental Impacts of Wastewater Use in Agriculture in Developing Countries. Working Paper 26. International Water Management Institute (IWMI), Colombo.

[8] Ujang, Z. and Henze, M. (Eds.) (2006) Municipal Wastewater Management in Developing Countries. Principles and Engineering, IWA Publishing, London.

[9] Jiménez-Cisneros, B. (1995) Wastewater Reuse to Increase Soil Productivity. Water Science and Technology, 32, 173-180. http://dx.doi.org/10.1016/0273-1223(96)00152-7

[10] Singh, P.K., Deshbhratar, P.B. and Ramteke, D.S. (2012) Effects of Sewage Wastewater Irrigation on Soil Properties, Crop Yield and Environment. Agricultural Water Management, 103, 100-104. http://dx.doi.org/10.1016/j.agwat.2011.10.022

[11] Yang, B., Kong, X., Cui, B., Jin, D., Deng, Y., Zhuang, X., Zhuang, G. and Bai, Z. (2015) Impact of Rural Domestic Wastewater Irrigation on the Physicochemical and Microbiological Properties of Pakchoi and Soil. Water, 7, 1825-1839.

http://dx.doi.org/10.3390/w7051825

[12] Hanjra, M.A., Blackwell, J., Carr, G., Zhang, F. and Jackson, T.M. (2012) Wastewater Irrigation and Environmental Health: Implications for Water Governance and Public Policy. International Journal of Hygiene and Environmental Health, 215, 255-269. http://dx.doi.org/10.1016/j.ijheh.2011.10.003

[13] Friedel, J.K., Langer, T., Siebe, C. and Stahr, K. (2000) Effects of Long-Term Wastewater Irrigation on Soil Organic Matter, Soil Microbial Biomass and Its Activities in Central Mexico. Biology and Fertility of Soils, 31, 414-421. http://dx.doi.org/10.1007/s003749900188

[14] Oved, T., Shaviv, A., Goldrath, T., Mandelbaum, R.T. and Minz, D. (2001) Influence of Effluent Irrigation on Community Composition and Function of Ammonia-Oxydizing Bacteria in Soil. Applied and Environmental Microbiology, 67, 3426-3433.

http://dx.doi.org/10.1128/AEM.67.8.3426-3433.2001

[15] Mohammad, M.J. and Mazahreh, N. (2003) Changes in Soil Fertility Parameters in Response to Irrigation of Forage Crops with Secondary Treated Wastewater. Communications in Soil Science and Plant Analysis, 34, 1281-1294. http://dx.doi.org/10.1081/CSS-120020444

[16] Ndour, N.Y.B., Baudoin E. and Guisse, A., Mountakha Seck, M., Khouma, M. and Brauman, A. (2008) Impact of Irrigation Water Quality on Soil Nitrifying and Total Bacterial Communities. Biology and Fertility of Soils, 44, 797-803. http://dx.doi.org/10.1007/s00374-008-0285-3

[17] Becerra-Castro, C., Lopes, A.R., Vaz-Moreira, I. Silva, E.F., Manaia, C.M. and Nunes, O.C. (2015) Wastewater Reuse in Irrigation: A Microbiological Perspective on Implications in Soil Fertility and Human and Environmental Health. Environment International, 75, 117135. http://dx.doi.org/10.1016/j.envint.2014.11.001

[18] Huang, G. (2015) From Water-Constrained to Water-Driven Sustainable Development-A Case of Water Policy Impact Evaluation. Sustainability, 7, 8950-8964. 
http://dx.doi.org/10.3390/su7078950

[19] Zhou, S., Huang, Y., Yu, B. and Wang, G. (2015) Effects of Human Activities on the EcoEnvironment in the Middle Heihe River Basin Based on an Extended Environmental Kuznets Curve Model. Ecological Engineering, 76, 14-26.

http://dx.doi.org/10.1016/j.ecoleng.2014.04.020

[20] Hu, X., Lu, L., Li, X., Wang J. and Guo, M. (2015) Land Use/Cover Change in the Middle Reaches of the Heihe River Basin over 2000-2011 and Its Implications for Sustainable Water Resources Management. PLoS ONE, 10, e0128960.

http://dx.doi.org/10.1371/journal.pone.0128960

[21] Hoshino, Y. and Matsumoto, N. (2004) An Improved DNA Extraction Method Using Skim Milk from Soils That Strongly Absorb DNA. Microbes and Environments, 19, 13-19. http://dx.doi.org/10.1264/jsme2.19.13

[22] Hui, L, Zhuwen, X., Shan, Y., Xiaobin, L., Eva, M.T., Ruzhen W., Yuge Z., Jiangping, C., Fei Y., Xingguo, H. and Yong, J. (2016) Responses of Soil Bacterial Communities to Nitrogen Deposition and Precipitation Increment Are Closely Linked with Aboveground Community Variation. Microbial Ecology, 71, 974-989. http://dx.doi.org/10.1007/s00248-016-0730-Z

[23] Griebler, C. and Lueders, T. (2009) Microbial Biodiversity in Groundwater Ecosystems. Freshwater Biology, 54, 649-677. http://dx.doi.org/10.1111/j.1365-2427.2008.02013.x

[24] Wilson, J.T., McNabb, J.F., Balkwill, D.L and Ghiorse, W.C. (1983) Enumeration and Characterization of Bacteria Indigenous to a Shallow Water-Table Aquifer. Groundwater, 21, 134-142. http://dx.doi.org/10.1111/j.1745-6584.1983.tb00710.x

[25] Phelps, T.J., Fliermans, C.B., Garland, T.R., Pfiffner, S.M. and White D.C. (1989) Methods for Recovery of Deep Terrestrial Subsurface Sediments for Microbiological Studies. Journal of Microbiological Methods, 9, 267-279. http://dx.doi.org/10.1016/0167-7012(89)90069-9

[26] Daims, H., Lebedeva, E.L., Pjevac, P., Han, P., Herbold, C., Albertsen, M., Jehmlich, N., Palatinszky, M., Vierheilig, J., Bulaev, A., Kirkegaard, R.H., von Bergen, M., Rattei, T., Bendinger, B., Nielsen, P.H. and Wagner, M. (2015) Complete Nitrification by Nitrospira Bacteria. Nature, 528, 504-509. http://dx.doi.org/10.1038/nature16461

[27] Janssen, P.H. (2006) Identifying the Dominant Soil Bacterial Taxa in Libraries of 16S rRNA and 16S rRNA Genes. Applied and Environmental Microbiology, 72, 1719-1728. http://dx.doi.org/10.1128/AEM.72.3.1719-1728.2006

[28] Armon, R., Gold, D., Brodsky, M. and Oron, G. (2002) Surface and Subsurface Irrigation with Effluents of Different Qualities and Presence of Cryptosporidium Oocysts in Soil and on Crops. Water Science \& Technology, 46, 115-122. 
Submit or recommend next manuscript to SCIRP and we will provide best service for you:

Accepting pre-submission inquiries through Email, Facebook, LinkedIn, Twitter, etc. A wide selection of journals (inclusive of 9 subjects, more than 200 journals)

Providing 24-hour high-quality service

User-friendly online submission system

Fair and swift peer-review system

Efficient typesetting and proofreading procedure

Display of the result of downloads and visits, as well as the number of cited articles

Maximum dissemination of your research work

Submit your manuscript at: http://papersubmission.scirp.org/

Or contact jwarp@scirp.org 